\title{
Reflexive positioning approach to the study of felicity and representations of happiness in the digital era
}

\author{
Natalia B. Kovaleva ${ }^{1 *}$, Vitaliy R. Minaev ${ }^{2}$, Anna V. Zueva ${ }^{3}$, and Lyubov Novozhilova ${ }^{4}$ \\ ${ }^{1}$ Moscow Pedagogical University, Institute of Childhood Department of Psychological Anthropology, \\ Moscow, Russia \\ ${ }^{2}$ HSE University, School of Psychology, Moscow, Russia \\ ${ }^{3}$ Moscow Regional State University, Moscow, Russia \\ ${ }^{4}$ Khoroshevskaya school, Moscow, Russia
}

\begin{abstract}
The article is devoted to the analysis of perceptions of what it means to be happy among modern Russians. The main focus of the study is to identify the level of subjective well-being of the respondents in association with their worldview ideas about happiness and the image of the world in representatives of different age groups. The paper gives a brief overview of the main studies of felicity, the concept of happiness, and subjective well-being. Based on the theoretical analysis of conceptual developments concerning the stages of development of moral consciousness, the value and meaning component of the image of the world, and the factors of subjective well-being, several models of happiness are constructed based on the results of content analysis and reflexive positioning analysis of the respondents' reflections. The research targets also include the ratio of the scales of subjective well-being (SW) and subjective happiness $(\mathrm{SH})$ or felicity and the nature of subjective satisfaction depending on the value-semantic model of ideas about happiness and the established image of the world. The study uses the methods of theoretical analysis and conceptual modeling, content analysis, and reflexive positional analysis of the text, a questionnaire including the scales of SW, SH, reflection on happiness, and the author's value-meaning diagnostic complex. The noteworthy results substantiating the novelty of the study show that: 1) The level of the subjective happiness scale is higher than the SB scale and shows a more positive orientation; 2) The respondents with the religious and existential models of happiness were the happiest based on the scales of subjective well-being and subjective happiness; the respondents with the consumer model of happiness were the least happy. Two new opportunities emerge from the point of further research prospects and the practice of psychological counseling and psychotherapy. First, there is an opportunity to diagnose the presence and nature of an intra-personal conflict in the presence of a notable gap between the values on the SW and SH scales. Second, it is possible to identify the reasons for deficits and the direction of development based on reflexive positioning analysis of free reflections on happiness.
\end{abstract}

\footnotetext{
* Corresponding author: nkovaig@mail.ru
} 
Keywords: reflexive positioning approach; models of happiness; subjective well-being; research targets.

\section{Introduction}

Many researchers indicate $[1,2]$ that despite quite a large body of research on the psychology of happiness both in Russian science [3-6] and abroad [7-10] the major portion of studies focuses on the subjective characteristics of ideas about happiness as the correlates of wellbeing, satisfaction, and quality of life in isolation from such personality characteristics as the worldview, the sphere of motivation and needs, value and meaning orientations, and positionality. Meanwhile, in the digital era, the metaphor of the flow drawing people into the rush and whirlpool of events, things, images, and reputations leads to an anthropological crisis associated primarily with the prevailing consumer or group-centered attitude to the world or the hedonistic orientation in society [11]. The way out of this situation calls for the creation of conditions for personality development by means of creative transformation of oneself and the world based on one's worldview ideals and value and meaning orientations $[1,12-15]$.

The purpose of the present work is to investigate the ideas of happiness, felicity, and subjective well-being of Russians in association with their value and meaning worldview and other personality characteristics. Another important objective of the study is also the identification of the model representations of happiness in correlation with the image of the world, value orientations, and positionality in the respondents' reflections.

The theoretical and methodological foundation of the study is formed by the concepts of happiness reflecting the existential aspect of human existence and value orientations $[8,16]$; conceptions of humanistic psychologists $[17,18]$ including K. Ryff's theory of psychological well-being comprising personal growth, self-acceptance, purpose in life, autonomy, environmental mastery, and positive relationships [19], as well as D.A. Leontiev's two-level model of happiness [1] and the four-level model of the development of a person's attitudes towards the world by B.S. Bratus. The first model introduces a distinction between the scarcity of happiness as a correlate of satisfaction of basic needs (and. from our point of view, values such as comfort, security, financial security, etc.) and the self-determination of happiness which implies the success of an individual existential project and meaningful life goals. In our interpretation, these levels characterize the consumer and existential models of happiness. The formulation of two more models of happiness, the social and the religious, that correlate with the image of the world is provided for B.S. Bratus' concept of happiness presenting four levels of attitude towards the world: the hedonistic or consumerist, the groupcentered or social-communicative, the prosocial or humanistic, and the religious or epistemological attitude toward the personal world [12]. We argue that it is the religious image that creates the conditions for a creative attitude towards the world and oneself underlying the idea of happiness under the condition of the development of the creativetransformative positionality of an individual [13].

\section{Study goal and methods}

The purpose of this study is to identify the characteristics and patterns associated with different aspects of the experience of happiness. The research targets include the correlation between the scales of subjective well-being (SW) and subjective happiness ( $\mathrm{SH}$ ) or felicity, the nature of subjective satisfaction depending on the value-meaning model of ideas about happiness and the established image of the world. The study uses the methods of theoretical analysis and conceptual modeling, content analysis and reflexive positioning analysis of the 
text, the author's questionnaire comprising the Perrudet-Badoux subjective well-being (SW) scale as adapted by M.V. Sokolova [20]; the modified subjective happiness or felicity scale by S. Lyubomirsky [21], as well as N.B. Kovaleva's value and meaning diagnostic complex tested in a number of studies $[13,22,23]$. The limitations of the applicability of SЦ scales are actively discussed in the literature $[1,24,25]$ due to the fact that they capture the selfperception of oneэs existential situation but take weak account of an individual's value and meaning and worldview ideals and psychological attitudes. The questionnaire developed for the present study includes the subjective well-being scale (SW) and N.B. Kovaleva's reflexive positioning questionnaire supplemented by a question on the self-assessment of happiness $(\mathrm{SH})$. Individual reflections of the respondents were initiated by asking them to share their thoughts on what happiness is, what distinguishes a happy person from an unhappy one, and what is the mystery of life. The pilot study involved 74 people from different regions of Russia (Moscow and the Moscow region, Irkutsk, Saint Petersburg, Rostov-on-Don, Ryazan, and Orel) aged 16 to 48.

\section{Results and discussion}

The main results of the survey on the scales of subjective well-being (SW) and felicity or subjective happiness ( $\mathrm{SH})$ and their correlations are presented in Table 1.

Table 1. Respondents' self-assessment results for the SH and SW scales

\begin{tabular}{|l|l|l|l|l|l|}
\hline Gradations & $\begin{array}{l}\text { Happiness } \\
\text { Scale (SH) self- } \\
\text { assessment } \\
\text { scores (felicity) }\end{array}$ & $\begin{array}{l}\text { Percentage } \\
\text { distribution } \\
\mathbf{( S H )} \\
\mathbf{\%}\end{array}$ & $\begin{array}{l}\text { Subjective } \\
\text { Well-being } \\
\text { Scale (SW) self- } \\
\text { assessment } \\
\text { scores }\end{array}$ & $\begin{array}{l}\text { Percentage } \\
\text { distribution } \\
\text { (SW) } \\
\mathbf{\%}\end{array}$ & $\begin{array}{l}\text { The ratio } \\
\text { of the SH } \\
\text { and SW } \\
\text { scale } \\
\text { scores }\end{array}$ \\
\hline gradation 1 & $\begin{array}{l}\text { Completely } \\
\text { happy }\end{array}$ & 16 & $\begin{array}{l}\text { Complete well- } \\
\text { being }\end{array}$ & 3 & 5.3 \\
\hline gradation 2 & Happy & 41 & Well-being & 28 & 1.5 \\
\hline gradation 3 & Rather happy & 24 & Rather well & 19 & 1.3 \\
\hline gradation 4 & $\begin{array}{l}\text { It varies } \\
\text { (ambivalence) }\end{array}$ & 11 & $\begin{array}{l}\text { It varies } \\
\text { (ambivalence) }\end{array}$ & 28 & -2.5 \\
\hline gradation 5 & Rather unhappy & 4 & Rather unwell & 14 & -3.5 \\
\hline gradation 6 & Unhappy & 3 & $\begin{array}{l}\text { Lack of well- } \\
\text { being }\end{array}$ & 7 & -2.3 \\
\hline gradation 7 & $\begin{array}{l}\text { Completely } \\
\text { unhappy }\end{array}$ & 1 & $\begin{array}{l}\text { Complete lack } \\
\text { of well-being }\end{array}$ & 1 & 1 \\
\hline gradations 1-3 & Total positive & 81 & Total positive & 50 & 1.6 \\
\hline gradation 4 & $\begin{array}{l}\text { Total } \\
\text { ambivalent }\end{array}$ & 11 & $\begin{array}{l}\text { Total } \\
\text { ambivalent }\end{array}$ & 28 & -2.5 \\
\hline gradations 5-7 & Total negative & 8 & Total negative & 22 & -2.8 \\
\hline
\end{tabular}

\section{Correlation of the results on the $\mathrm{SH}$ and $\mathrm{SW}$ scales}

As follows from the statistical analysis, the integral self-assessment of SW, in contrast to the felicity scale, has a much greater range of negative assessments of one's well-being. The results also show that the total of positive assessments on the happiness scale is 1.6 times higher, and completely satisfactory assessments are 5.3 times more prevalent. Vice versa, the negative assessments of SW are almost three times more common than negative evaluations of felicity. That is, people are inclined to consider themselves generally happy but their well- 
being, which depends more on living conditions and circumstances, is assessed more critically, and a third of respondents assess their situation as unfavorable.

Qualitative analysis of the obtained data shows a significant gap between the values of the SW and SH scales in half of the respondents (52\% of the participants), and the scores on the SH scale are unambiguously positive in $60 \%$ of the cases while the values on the SW scale are ambivalent or negative, and in some cases $(38 \%)$ are in sharp contrast $(10: 3 ; 8: 2$; 7:1 and other similar values).

\section{Results of the reflexive positioning analysis of reflections on happiness}

The analysis of texts in terms of the nature of value orientations of positionality and the image of the world allow identifying several models of ideas about happiness in the minds of respondents. The majority of the respondents considering themselves completely happy (gradation 1) base their thoughts about happiness on religious $(36 \%)$ or existential $(27 \%)$ images of happiness in conjunction with the creative $(27 \%)$ or creative-religious $(10 \%)$ orientations. Moreover, their ideas are mostly consistent with their worldview position and the image of the world: they directly coincide or have high scores. This trend supports the initial assumption that people with more pronounced spiritual interests having a creative position, religious self-awareness, or existential worldview prove to be more mature and highly spiritual personalities and, accordingly, not only feel happy but actively support the attitude to happiness and its active attainment for themselves and others.

\section{Statistical data analysis}

The main step of the study was to test the hypothesis that there is a connection between the individual model of happiness and the levels of subjective well-being and happiness. Significant differences are found for the scale of subjective self-assessment of happiness between the respondents with religious and existential models and the respondents with the consumer model. Data analysis shows that the subjective assessment of happiness is lower in the consumer group.

The results of the Mann-Whitney test comparing the level of subjective well-being in the groups with religious and consumer models of happiness (significance level - 0.09) are presented in Table 2 .

Table 2. Comparison of the level of subjective well-being in groups with religious and consumer models of happiness

\begin{tabular}{|l|l|l|}
\hline Scale & Religious model: average rank & Consumer model: average rank \\
\hline Subjective well-being & 9.13 & 9.80 \\
\hline
\end{tabular}

The results of the Mann-Whitney test comparing the level of subjective well-being in the groups with existential and consumer models of happiness (significance level -0.112 ) are presented in Table 3.

Table 3. Comparison of the level of subjective well-being in groups with existential and consumer models of happiness

\begin{tabular}{|l|l|l|}
\hline Scale & Existential model: average rank & Consumer model: average rank \\
\hline Subjective well-being & 10.92 & 13.40 \\
\hline
\end{tabular}




\section{Conclusion}

As a result, we should note several trends that constitute the novelty of the study. 1. In most cases, the level on the subjective happiness scale is higher than the subjective well-being scale and has a more positive orientation; 2 . The happiest on the scales of subjective wellbeing and subjective happiness are the respondents with religious and existential worldviews, the least satisfied are the respondents with the consumerist worldview regardless of their age group.

Two new opportunities emerge in terms of prospects for further research and practice of psychological counseling and psychotherapy. First, there is an opportunity to diagnose the presence and nature of an intra-personal conflict in the presence of a notable gap between the values on the SW and SH scales. Second, it is possible to identify the reasons for deficits and the direction of development based on reflexive positioning analysis of free reflections on happiness.

\section{References}

1. D.A. Leontiev, Monitoring of Public Opinion: Economic and Social Changes, 1, 14-37 (2020)

2. E. N. Osin, D. A. Leontiev, Monitoring of Public Opinion: Economic and Social Changes, 1, 117-142 (2020). https://doi.org/10.14515/monitoring.2020.1.06.

3. O. V. Liusova, Logos et Praxis, 16(4), 97-194 (2017). https://doi.org/10.15688/lp.jvolsu.2017.4.10

4. E.B. Laktionova, M.G. Matiushina, Bulletin of Irkutsk State University. Series: Psychology, 26, 77-88 (2018)

5. A.M. Rikel, A.A. Tuniiants, N. Batyrova, Bulletin of Moscow University. Series 14. Psychology, 2, 64-82 (2017)

6. I.V. Sidorenko, Bulletin of Moscow University. Series 7. Philosophy, 2, 95-100 (2007)

7. E. Diener, L. Tay, A Scientific Review of the Remarkable Benefits of Happiness for Successful and Healthy Living, in: Happiness: Transforming the Development Landscape, 90-117 (The Centre for Bhutan Studies and GNH, Thimphu, 2017)

8. V. Huta, Eudaimonic and Hedonic Orientations: Theoretical Considerations and Research Findings, in: Vittersø J. (ed.) Handbook of Eudaimonic Well-Being, 215-231 (Springer, Cham, 2016). https://doi.org/10.1007/978-3-319-42445-3_15.

9. M. E.P. Seligman, Authentic Happiness: Using the New Positive Psychology to Realize Your Potential for Lasting Fulfillment (The Free Press, New York, 2002)

10. W. Tov, Well-being concepts and components, in E. Diener, S. Oishi, L. Tay (Eds.), Handbook of well-being (DEF Publishers, Salt Lake City, UT, 2018).

11. B.S. Bratus, Journal of the Higher School of Economics, 16(3), 470-478 (2019). https://doi.org/10.17323/1813-8918-2019-3-470-478

12. B.S. Bratus, Obraz cheloveka v psikhologii Rossii XX veka. [The image of a person in Russian psychology of the 20th century.] (Razvitie lichnosti, Moscow, 2009)

13. N.B. Kovaleva, F.A. Kovalev, Refleksivno-pozitsionnyi podkhod k razvitiiu lichnosti i sposobnostei uchashchikhsia. Mediagermenevtika. Uchebno-metodicheskoe posobie. [Reflexive positioning approach to the development of personality and abilities of students. Mediahermeneutics. Educational-methodical manual.] (Moscow State Pedagogical University, Moscow, 2018) 
14. N.B. Kovaleva, K.S Ezhov, O.E. Chernova, M.G. Leontev, S.N. Kazakova, Journal of Human Sport and Exercise, 14(5proc), 2103-2115 (2019).

https://doi.org/10.14198/jhse.2019.14.Proc5.31

15. V. I. Slobodchikov, Bulletin of Saint Petersburg University, 1, 100-108 (2016)

16. I.A. Dzhidarian, Psychological Journal, 21(2), 40-48 (2000)

17. A. H. Maslow, Toward a Psychology of Being (Van Nostrand, New York, 1968)

18. A. A. Langle, E. M. Ukolova, V. B. Shumskii, Sovremennyi ekzistentsialnyi analiz: istoriia, teoriia, praktika, issledovaniia: monografiia [Modern Existential Analysis: History, Theory, Practice, and Research: A Monograph] 2nd ed. (Iurait publishing house, Moscow, 2020)

19. C. D. Ryff, C. L.M. Keyes, Journal of Personality and Social Psychology, 69(4), 719727 (1995) https://doi.org/10.1037/0022-3514.69.4.719.

20. V.V. Kozlov, V.A. Mazilov, N.P. Fetiskin, Sotsialno-psikhologicheskaia diagnostika razvitiia lichnosti i malykh grupp [Socio-psychological diagnostics of the development of personality and small groups], 562-565 (Institute of Psychotherapy and Clinical Psychology, Moscow, 2018)

21. S. Lyubomirsky, H. S. Lepper, Social Indicators Research, 46(2), 137-155 (1999) https://doi.org/10.1023/a:1006824100041

22. S.V. Danilcheva, Azimuth of Scientific Research: Pedagogy and Psychology, 8(4(29)), 287-290 (2019)

23. O.V. Mikheeva, International Scientific Journal Symbol of Science, 7-2(19), 146-149 (2016)

24. E. Diener, S. Oishi, L. Tay (eds.) Handbook of Well-Being (DEF Publishers, Salt Lake City, UT, 2018)

25. K. Sheldon, S. Lyubomirsky, The Journal of Positive Psychology, 16(9), 1-10 (2019). https://doi.org/10.1080/17439760.2019.1689421. 